\title{
Validation of the short form of the career development inventory with an Iranian high school sample
}

\author{
Ahmad Sadeghi • Iran Baghban • Fatemeh Bahrami • \\ Ahmad Ahmadi $\cdot$ Peter Creed
}

Received: 15 January 2010/Accepted: 15 December 2010/Published online: 3 March 2011

(C) The Author(s) 2011. This article is published with open access at Springerlink.com

\begin{abstract}
A short 33-item form of the Career Development Inventory was validated on a sample of 310 Iranian high school students. Factor analysis indicated that attitude and cognitive subscale items loaded on their respective factors, and that internal reliability coefficients at all levels were satisfactory to good. Support for validity was demonstrated by associations in the expected direction for career decidedness and career decision-making self-efficacy. This short form of the inventory shows promise as a measure of career maturity with students from a non-Western country.
\end{abstract}

Résumé. Validation de la version courte du Career Development Inventory avec un échantillon de lycéens iraniens. Une version courte à 33 items du Career Development Inventory a été validée sur un échantillon de 310 étudiants iraniens au lycée. L'analyse factorielle indique que les items des échelles attitude et cognition saturent sur leurs facteurs respectifs et que les coefficients de fidélité interne sont satisfaisants à bons à tous les niveaux. Un soutien à la validité est démontrée par l'association dans la direction attendue entre la décision vocationnelle et le sentiment de compétence en ce qui concerne la prise de décision vocationnelle. La version courte de cet inventaire est prometteur en tant que mesure de la maturité vocationnelle avec des étudiants d'un pays non occidental.

Zusammenfassung. Validierung der Kurzform des Career Development Inventory mit einer Gruppe iranischer Gymnasiasten. Eine kurze 33-Item Form des Career Development Inventory wurde an einer Stichprobe von 310 iranischen Gymnasiasten validiert. Eine Faktor-Analyse zeigte, dass die Items der Subskalen

\footnotetext{
A. Sadeghi $(\bowtie) \cdot$ I. Baghban · F. Bahrami · A. Ahmadi

Faculty of Psychology, Department of Counselling, University of Isfahan, Isfahan,

Islamic Republic of Iran

e-mail: asadeghi22@gmail.com

P. Creed

Griffith University, Brisbane, QLD, Australia
} 
Einstellung und Kognition auf ihre jeweiligen Faktoren laden, und dass die internen Reliabilitätskoeffizienten auf allen Ebenen befriedigend bis gut waren. Die Validität wurde durch Beziehungen in der erwarteten Richtung zur beruflichen Entschiedenheit und Selbstwirksamkeitserwartung in der Berufswahl demonstriert. Diese Kurzform des Fragebogens ist vielversprechend als ein Messinstrument der Berufswahlreife mit Schülern aus einem nicht-westlichen Land.

\section{Resumen. Validación de una forma abreviada del Inventario del Desarrollo de la Carrera, con una muestra iraní de estudiantes de secundaria. Una forma abreviada (33 items) del Inventario del Desarrollo de la Carrera se validó con una muestra de 310 estudiantes de secundaria iraníes. Los análisis factoriales mostraron que los items de las sub-escalas actitudinal y cognitiva saturaron en sus respectivos factores y que los coeficientes de fiabilidad interna puntuaron entre satisfactorio y bien, en todos los niveles. La validez se demostró a través de la relación, en la dirección esperada, entre la determinación vocacional y la auto-eficacia en la toma de decisiones. Esta forma abreviada del inventario es potencialmente útil para medir la madurez vocacional de estudiantes de un país no occidental.}

Keywords Career development inventory - Career maturity · Career planning

\section{Introduction}

Super's $(1957,1990)$ career development theory and its central construct of career maturity have received considerable attention across many countries, including the United States (e.g., Levinson, Ohler, Caswel, \& Kiewra, 1998; Savickas \& Hartung, 1996; Super, Osborne, Walsh, Brown, \& Niles, 1992), Australia (e.g., Clayton \& Fletcher, 1994; Creed \& Patton, 2003; Patton \& Creed, 2001), Canada (Perron, Vondaracek, \& Skorikov, 1998), Korea (Lee, 2001) and Thailand (Hughes \& Thomas, 2006). According to Crites (1976) the central concept for understanding career behaviour is career maturity. Career maturity refers to the individual's readiness to make informed, age-appropriate career decisions and to manage the career development tasks with which the individual is confronted (Savickas, 1984). Crites (1971) proposed that career maturity consisted of cognitive and affective dimensions, with the cognitive dimension being composed of decision-making skills and the affective dimension assessing attitudes about the career decision-making process. The career maturity construct has great practical utility (Raskin, 1998), and has shaped career interventions for adolescents in a myriad of settings (Creed \& Patton, 2003).

Several assessment instruments have been developed to measure the construct of career maturity, including the Career Maturity Inventory (Crites, 1973), the Career Development Inventory (Super, Thompson, Jordaan, Lindeman, \& Myers, 1988), the Adult Career Concerns Inventory (Super et al., 1988), the Assessment of Career Decision Making (Buck \& Daniels, 1985; Haren, 1979), the Career Beliefs Inventory (Krumboltz, 1994), and the Career Decision Scale (Osipow, Carney, Winer, Yanico, $\&$ Koschier, 1976). One of the more widely used scales for measuring career maturity is the 120-item Career Development Inventory (CDI; Super et al., 1988). This scale, 
which was developed in the US, incorporates two attitudinal subscales (Career Planning, Career Exploration), two general cognitive subscales (Decision Making, World of Work Information), and one specific cognitive subscale (Knowledge of Preferred Occupational Group). Typically, the Career Planning and Exploration subscales are summed to provide a composite attitudinal score (Career Development Attitude), and Decision Making and World of Work Information are summed to provide a composite cognitive score (Career Development Knowledge).

Lokan (1984) developed an Australian version of the Career Development Inventory (CDI-A) based on the US version. The CDI-A contains 72 Items (achieved mainly by omitting the Knowledge of Preferred Occupational Group subscale) and includes Australia-relevant questions. In the CDI-A, the career planning subscale is rated on four-choice sentence completion scale, while the CDI has five-point Likert-type scale, from 1 (not much) to 5 (a great deal). In addition, the items in the Career Exploration subscale are not weighted and contain fewer items (16 rather than 20) and Decision Making subscales (12 rather than 20). The CDI-A has been widely used in Australia (e.g., Clayton \& Fletcher, 1994; Creed \& Patton, 2003; Patton \& Creed, 2001) and in other countries, such as South Africa (Patton, Watson \& Creed, 2004) and Thailand (Hughes \& Thomas, 2006).

Creed and Patton (2004) developed and validated a short form of the CDI-A. They used a sample of 2,173 high school students enrolled in grades 8-12 to develop a 33-item short form (CDI-A-SF) of the 72-item CDI-A. As with the original CDI-A, the CDI-A-SF is comprised of two attitudinal subscales (Career Planning and Exploration) and two cognitive subscales (Decision Making and World of Work Information). The Career Planning subscale addresses areas such as discussing plans with an adult, choosing school subjects relevant to a future job, and knowledge of job duties and working conditions. The Career Exploration subscale addresses possible sources of advice and information about careers. The World of Work Information subscale covers content areas of information life stages, developmental tasks, job seeking and job training. The Decision Making subscale covers the domain areas of understanding the relative importance of different types of occupations, and personal and situational characteristics relevant to different jobs.

Evidence of the construct validity of the shortened version was obtained in three ways. First, factor analysis demonstrated that the factor structure of the CDI-A-SF was consistent with the original factor structure of the CDI-A. Second, associations between the CDI-A-SF and other career relevant variables (e.g., career indecision, career certainty, career decision-making self-efficacy, and self-esteem) supported convergent and divergent validity. Third, appropriate age differences were identified, and older students reported higher levels of career maturity than younger students (Creed \& Patton, 2004). The authors concluded that the CDI-A-SF showed promise as a career maturity measure for adolescents and may be useful in situations where it is not possible or inappropriate to use the full scale. Similar to the CDI-A, the CDI-A-SF can be interpreted at the subscale and composite scale levels.

The current study is a replicated work of the main study that was done by Creed and Patton (2004). The main purpose of this study was to validate the 33-item CDIA-SF with an Iranian sample. To date, no appropriate measure of career 
development has been devised for Iranian adolescents. It is important for Iranian high school students to assess their career maturity because they have to determine the high school track relevant to their future job before being admitted to the university. However, in the Iranian education system, there isn't a career counselling course or program that addresses issues of self-awareness, career exploration, or career planning, and there isn't an existing measure to assess career development. Because of these limitations, it seems to be necessary to provide a valid measure for Iranian high school students. So, the current study aimed to extend the application of the CDI-A-SF to an Iranian population.

\section{Method}

Translation

The English-version of the CDI-A-SF was translated into Farsi and confirmed by three bilingual experts in career development. Then, the Farsi form was backtranslated into English and sent to one of the main authors of the CDI-A-SF (Creed), who confirmed the back-translation. However, there are differences between Iranian and Australia educational systems; notably, the curriculum in the Iranian educational system is fixed and high school students cannot choose their subjects. Therefore, three items from the Career Planning subscale were modified. For example, "Taking school subjects that will help me in the work I go into when I finish my education" was changed to "The part-time work that I engage in will help me in the work I go into when I finish my education." "Taking school subjects that will help me in college or university, in job training or on the job" was changed to "Train or study in courses that will help me in college or university, in job training or on the job." And, "Choosing school subjects (including options and electives)" was changed to "Choosing a school track that fits with the future job."

\section{Participants}

Participants were 310 high school students enrolled in grades 9-11 in four schools in Isfahan, which is Iran's third largest city after Tehran and Mashhad, with a population of 1.5 million people. The students had a mean age of 16.41 years $(S D=1.32$ years), and included 156 females $(50.3 \%)$ and 154 males (49.7\%); 100 $(32.3 \%)$ were in grade $9,114(36.8 \%)$ were in grade 10 , and $95(30.6 \%)$ were in grade 11 .

\section{Measures}

Career development inventory-Australia-short form. Creed and Patton's (2004) CDI-A-SF was used to measure career maturity. This short version has 33 items, and is designed for students in grades 8-12. Four subscales and two composite scales are typically calculated. The four subscales are Career Planning (10 items), Career Exploration (8 items), World of Work Information (8 items) and Career 
Decision Making (7 items). Scores on the Career Planning and Career Exploration scales may be combined to measure Career Development Attitude, and scores on the World of Work Information and Career Decision Making scales may be summed to measure Career Development Knowledge. Creed and Patton (2004) assessed construct validity using factor analysis and testing the scale's association with other career variables, and reported satisfactory internal reliability coefficients for all subscales (ranging from .70 to .87) and the two composite scales (.82 and .87).

Career decision-making scale. The Career Decision-Making Scale (Osipow et al., 1976) was used to measure decision-making readiness. The 19-item scale consists of two subscales: Career Indecision (16 items; e.g., "Several careers have equal appeal to me. I'm having a difficult time deciding among them") and Career Decidedness (3 items; e.g., "I have decided on a career and feel comfortable with it. I also know how to go about implementing my choice"). The students responded to the items using a 4-point Likert-type scale ranging from 1 (not at all like me) to 4 (exactly like me). Higher scores indicated more indecision and more certainty, respectively. Karimi (2007) reported adequate validity for the scale and indicated satisfactory internal reliabilities (.80) for an Iranian sample.

Career decision-making self-efficacy scale. The 25-item short version of the Career Decision-Making Self-Efficacy Scale (Betz, Klein, \& Taylor, 1996) was used to assess confidence regarding ability to make career-oriented decisions. Students rated their level of confidence on a 5-point Likert-type scale, ranging from 1 (no confidence at all) to 5 (complete confidence), to questions such as, "How confident are you that you could determine what your ideal job would be?" Higher scores indicated more career-related confidence. In Iran, Karimi (2007) reported adequate validity for the scale, and indicated satisfactory internal reliability (.92).

\section{Procedure}

Participants included 310 randomly chosen 9 th to 11 th grade high school students who were informed about the research purpose and asked to answer all of the questionnaires. Participants were recruited using cluster sampling, whereby the researchers randomly chose four high schools (two male, two female) from one randomly chosen district of five in Isfahan. Participants' classroom teachers administered all questionnaires. Students were assured that all their information would remain confidential and informed that they could learn more about their individual results from their school counsellor 1 month after administration time.

\section{Results}

Means, standard deviations, and internal reliability coefficients were generated for the four subscales and two composite scales for the Iranian high school sample. These are reported in Table 1, along with comparable data reported by Creed and Patton (2004). The internal reliability coefficients for the Iranian sample ranged from .64 to .82 for the subscales, and from .74 to .82 for the composite scales, 
suggesting satisfactory internal reliability, and internal reliability comparable with that reported by Creed and Patton.

\section{Validity}

Construct validity of the CDI-A-SF was investigated in two ways. First, the factor structure of the CDI-A-SF was tested using factor analysis; and second, the relationship between the CDI-A-SF and other career relevant variables (career indecision, career certainty, career decision-making self-efficacy) was assessed. To test if the factor structure of the CDI-A-SF was consistent with the original CDI structure, we examined (a) whether the individual items loaded on their respective subscales, and (b) whether the individual subscales loaded on their respective attitudinal and knowledge factors.

First, the items comprising the attitudinal domains of Career Planning and Career Exploration were subjected to a principal axis factor analysis with oblique rotation. The KMO Measure of Sampling Adequacy was .81 and Bartlett's Test of Sphericity was significant $(p<.001)$. Two factors explained $44.7 \%$ of the variance. For the most part, individual items loaded onto their respective factors, except item 3 on the Career Planning subscale. Table 2 details the factor loading for career planning, which ranged from .31 to .69 and from .35 to .69 for career exploration.

Second, the total scores for the attitudinal domains (career planning and career exploration) and the cognitive subscales (World of Work Information and Career Decision Making) were subjected to principal axis factor analysis with oblique rotation and are displayed in Table 3. The KMO Measure of Sampling Adequacy for this analysis was .68 and the Bartlett's Test of Sphericity was significant $(p<.001)$. Two factors explained $70.46 \%$ of the variance. All subscales loaded on their appropriate factors, with factor loadings ranging from .84 to .87 .

Table 1 Means, standard deviations, and internal reliability coefficients for the career development inventory-short form

\begin{tabular}{|c|c|c|c|c|c|c|}
\hline & \multicolumn{3}{|c|}{ Present study } & \multicolumn{3}{|c|}{ Creed and Patton (2004) } \\
\hline & \multicolumn{3}{|c|}{$\begin{array}{l}\text { High school students } \\
\text { (Years 9-11) } \\
N=310\end{array}$} & \multicolumn{3}{|c|}{$\begin{array}{l}\text { High school students } \\
\text { (Years 8-12) } \\
N=2173\end{array}$} \\
\hline & $\alpha$ & $M$ & $S D$ & $\alpha$ & $M$ & $S D$ \\
\hline \multicolumn{7}{|l|}{ Subscales } \\
\hline Career planning & $.82^{\mathrm{a}}$ & 34.87 & 5.72 & $.87^{\mathrm{a}}$ & 33.30 & 7.07 \\
\hline Career exploration & $.66^{\mathrm{a}}$ & 22.88 & 5.35 & $.73^{\mathrm{a}}$ & 19.5 & 4.80 \\
\hline World of work knowledge & $.66^{\mathrm{b}}$ & 4.39 & 1.83 & $.73^{\mathrm{c}}$ & 5.50 & 2.15 \\
\hline Career decision making & $.64^{\mathrm{b}}$ & 3.06 & 1.58 & $.70^{\mathrm{c}}$ & 3.49 & 2.05 \\
\hline \multicolumn{7}{|l|}{ Composite scales } \\
\hline Career development attitude & $.82^{\mathrm{a}}$ & 57.84 & 9.38 & $.87^{\mathrm{a}}$ & - & - \\
\hline Career development knowledge & $.74^{\mathrm{b}}$ & 7.45 & 2.91 & $.82^{\mathrm{c}}$ & - & - \\
\hline
\end{tabular}

${ }^{\mathrm{a}}$ Cronbach's alpha; ${ }^{\mathrm{b}}$ Split-half internal reliability; ${ }^{\mathrm{c}}$ Kuder-Richardson 20 
Table 2 Principal axis factor analysis with oblique rotation of the attitudinal subscales of the CDI-A-SF; $N=310$ this study and Creed and Patton's study (2004)

\begin{tabular}{|c|c|c|c|c|}
\hline \multirow[t]{2}{*}{ Item } & \multicolumn{2}{|c|}{ This study } & \multicolumn{2}{|c|}{$\begin{array}{l}\text { Creed and Patton's } \\
\text { study (2004) }\end{array}$} \\
\hline & $\begin{array}{l}\text { Factor } 1 \\
\text { Career } \\
\text { planning }\end{array}$ & $\begin{array}{l}\text { Factor } 2 \\
\text { Career } \\
\text { exploration }\end{array}$ & $\begin{array}{l}\text { Factor } 1 \\
\text { Career } \\
\text { planning }\end{array}$ & $\begin{array}{l}\text { Factor } 2 \\
\text { Career } \\
\text { exploration }\end{array}$ \\
\hline 1 & .54 & .40 & .34 & .09 \\
\hline 2 & .31 & .18 & .79 & .00 \\
\hline 3 & .29 & .18 & .75 & .05 \\
\hline 4 & .55 & .28 & .52 & .04 \\
\hline 5 & .46 & .36 & .38 & .00 \\
\hline 6 & .56 & .14 & .34 & .07 \\
\hline 7 & .69 & .20 & .81 & -.03 \\
\hline 8 & .69 & .24 & .85 & .05 \\
\hline 9 & .60 & .14 & .83 & .02 \\
\hline 10 & .58 & .24 & .59 & .18 \\
\hline 11 & .25 & .39 & .05 & .76 \\
\hline 12 & .21 & .56 & .03 & .74 \\
\hline 13 & .17 & .69 & -.04 & .49 \\
\hline 14 & .37 & .65 & -.04 & .40 \\
\hline 15 & .14 & .54 & -.06 & .56 \\
\hline 16 & .20 & .45 & .22 & .47 \\
\hline 17 & .06 & .35 & -.01 & .55 \\
\hline 18 & .45 & .56 & -.03 & .52 \\
\hline Eigenvalue & 3.97 & 1.51 & 5.89 & 1.7 \\
\hline$\%$ Variance & 22.10 & 8.39 & 32.69 & 9.45 \\
\hline Factor correlation & .38 & & .44 & \\
\hline
\end{tabular}

Third, Table 4 displays results from the associations tested between the four subscales of the CDI-A-SF (Career Planning, Career Exploration, World of Work Information, and Career Decision Making), the two composite scales (Career Development Attitude and Career Development Knowledge) and the scales measuring career decision-making self-efficacy, career decision-making indecision, and career decision-making certainty.

The CDI-A-SF attitudinal subscales (Career Planning and Career Exploration) were significantly correlated $(r=.46$ ), as were the knowledge subscales (World of Work Information and Career Decision Making; $r=.44$ ); and the attitudinal subscales were more highly correlated with one another than they were with the knowledge subscales (range: $r=.09$ to .22 ). The knowledge subscales were more highly correlated with the composite knowledge scale (range: $r=.83$ to .87 ) than they were with the composite attitude scale (range: $r=.15$ to .18). The CDI-A-SF subscales and composite scales were uncorrelated with career decision-making and indecision (range: $r=-.09$ to .02 ); positively, albeit weakly, correlated with career decision-making certainty (range: $r=.06$ to .27 ); and positively associated with 
Table 3 Principal axis factor analysis with oblique rotation of the attitudinal and cognitive subscales; $N=310$

\begin{tabular}{lcc}
\hline & $\begin{array}{l}\text { Factor 1: } \\
\text { Career } \\
\text { development } \\
\text { knowledge }\end{array}$ & $\begin{array}{l}\text { Factor 2: } \\
\text { Career } \\
\text { development } \\
\text { attitude }\end{array}$ \\
\hline $\begin{array}{l}\text { Attitudinal subscales } \\
\text { Career planning }\end{array}$ & .27 & $\mathbf{- . 8 4}$ \\
$\begin{array}{l}\text { Career exploration } \\
\text { Cognitive subscales } \\
\text { World of work } \\
\text { information }\end{array}$ & .04 & -.87 \\
$\begin{array}{l}\text { Career decision } \\
\text { making }\end{array}$ & $\mathbf{. 8 5}$ & -.17 \\
$\begin{array}{l}\text { Eigenvalue } \\
\text { \% Variance }\end{array}$ & $\mathbf{. 8 5}$ & -.13 \\
\begin{tabular}{l} 
Factor correlation \\
\hline
\end{tabular} & 1.73 & 1.19 \\
\hline
\end{tabular}

Table 4 Pearson's product-moment correlations between the CDI-A-SF and career decision-making self-efficacy, career decision-making indecision and career decision-making certainty; $N=310$

\begin{tabular}{|c|c|c|c|c|c|c|c|c|}
\hline & 1 & 2 & 3 & 4 & 5 & 6 & 7 & 8 \\
\hline 1. Career planning & - & & & & & & & \\
\hline 2. Career exploration & $.46^{* *}$ & - & & & & & & \\
\hline 3. World of work information & $.22 * *$ & .09 & - & & & & & \\
\hline 4. Career decision making & $.17 * *$ & .09 & $.44 * *$ & - & & & & \\
\hline 5. Career development attitude & $.87 * *$ & $.84 * *$ & $.18 * *$ & $.15^{*}$ & - & & & \\
\hline 6. Career development knowledge & $.23 * *$ & .10 & $.87 * *$ & $.83 * *$ & $.19 * *$ & - & & \\
\hline 7. Career certainty & .16 & $.27^{*}$ & .13 & .21 & .21 & .19 & - & \\
\hline 8. Career indecision & -.09 & -.09 & -.06 & .02 & -.09 & -.03 & $-.35 * *$ & - \\
\hline 9. Decision-making self-efficacy & $.41 * *$ & .19 & $.29 *$ & $.33 *$ & $.35^{*}$ & $.35^{* *}$ & $.35 * *$ & -.26 \\
\hline
\end{tabular}

$* p<.05, * * p<.01$

career decision-making self-efficacy (range: $r=.19$ to .41 ). These findings supported the construct validity of the CDI-A-SF.

\section{Discussion}

The present study provided support for using the 33-item CDI-A-SF with Iranian high school students. Satisfactory to good internal reliability coefficients were obtained for all subscales (Career Planning, Career Exploration, World of Work Knowledge, and Decision-Making), and high internal reliability coefficients were recorded for the two composite scales (Career Development Attitude and Career Development Knowledge). These coefficients were comparable to those found by Creed and Patton (2004) using a similar sample of Australian students.

Construct validity for the test was supported using factor analysis, with individual items loading largely where expected. The two attitudinal subscales 
(Career Planning and Career Exploration) and the two cognitive subscales (World of Work Knowledge and Decision-making) loaded onto their respective factors, except item 3 in Career Planning subscales. Despite adapting the third item to reflect Iranian cultural and educational customs, equal facilities and access to certain courses that aid in job training do not exist as they do elsewhere; therefore, this item did not load on its respective factor. Inter-scale correlations were larger between the attitudinal subscales, and between the cognitive subscales, than they were across the attitudinal and cognitive subscales. The two composite scales (Career Development Attitude, Career Development Knowledge) were weakly correlated.

Validity was supported by testing correlations between the CDI-A-SF, the Career Decision Scale, and the Career Decision-Making Self-Efficacy Scale. Career maturity was positively associated with career certainty and career decision-making self-efficacy (i.e., the higher the career maturity, the more certainty about career direction and the more career-related confidence), and largely unrelated to career indecision.

Taken together, these findings provide support for the reliability, content validity and construct validity of the CDI-A-SF when used with Iranian high school students. Due to the lower internal reliability coefficients for all subscales, it is recommended that interpretation of the CDI-A should occur at the composite scale level.

The recent focus on lifelong career development and multiple career changes has highlighted the relevance of career maturity as a way of understanding the progress of individuals of all ages through the mini-cycles of career transitions (Super, 1990). The 33-item CDI-A-SF appears to be a promising version of the CDI-A for Iranian high school students in career change, when interpreted at the two-factor level (i.e., using the Career Development Attitude and Career Development Knowledge composite scales). Further testing in Iran is required to assess a more heterogeneous sample of Iranian children (i.e., from different cities, and from rural areas). The current study, however, has provided encouragement for the utility of this work. In addition, the assessment of Iranian students' career maturity is so necessary in high school, because in this period of study they need to be more informed about what career step (according to Super's theory) they are in. This information can greatly help to provide early career guidance in order to help students clarify their self-concepts.

Given the dearth of appropriate and psychometrically sound short measures of career maturity in the career development literature in general, and the lack of any scales in the Farsi language, it is important to continue to explore the usefulness of this measure.

Open Access This article is distributed under the terms of the Creative Commons Attribution Noncommercial License which permits any noncommercial use, distribution, and reproduction in any medium, provided the original author(s) and source are credited.

\section{References}

Betz, N. E., Klein, K. L., \& Taylor, K. M. (1996). Evaluation of a short form of the Career DecisionMaking Self-Efficacy Scale. Journal of Career Assessment, 4, 47-57. 
Buck, J. N., \& Daniels, M. G. (1985). Assessment of Career Decision Making (ACDM) manual. Los Angeles, CA: Western Psychological Services.

Clayton, L., \& Fletcher, J. (1994). Are realistic types really less career mature? Year 10 differences in career maturity between Holland's work personality types. Australian Journal of Career Development, 3, 29-34.

Creed, P. A., \& Patton, W. (2003). Differences in career attitude and career knowledge for high school students with and without paid work experience. International Journal for Educational and Vocational Guidance, 3, 21-33.

Creed, P. A., \& Patton, W. (2004). The development and validation of a short form of the Career Development Inventory-Australia. Australian Journal of Guidance and Counseling, 14, 125-138.

Crites, J. (1971). The maturity of vocational attitudes in adolescence. Washington, DC: American Personnel and Guidance Association.

Crites, J. (1973). The Career Maturity Inventory. Monterey, CA: CTB/McGraw Hill.

Crites, J. (1976). A comprehensive model of career development in early adulthood. Journal of Vocational Behavior, 9, 105-118.

Haren, V. A. (1979). A model of career decision making for college students. Journal of Vocational Behavior, 14, 119-133.

Hughes, C., \& Thomas, T. (2006). Adapting the Career Development Inventory-Australia for crosscultural research. Journal of Vocational Behavior, 69, 276-288.

Karimi, A. (2007). Effect of career decision skills training on career decision making self efficacy and career indecision on Isfahan University student. Quarterly Journal of Counseling Research and Development, 28, 43-58.

Krumboltz, J. D. (1994). The Career Beliefs Inventory. Journal of Counseling and Development, 72, 424-428.

Lee, K. H. (2001). A cross-cultural study of the career maturity of Korean and United States high school students. Journal of Career Development, 28, 43-57.

Levinson, E. M., Ohler, D. L., Caswel, S., \& Kiewra, K. (1998). Six approaches to the assessment of career maturity. Journal of Counseling and Development, 76, 475-482.

Lokan, J. (1984). Manual of the Career Development Inventory-Australian Edition. Melbourne, Australia: Australian Council for Educational Research.

Osipow, S. H., Carney, C. G., Winer, J., Yanico, B., \& Koschier, M. (1976). The Career Decision Scale. Columbus, OH: Marathon Consulting Press.

Patton, W., \& Creed, P. A. (2001). Developmental issues in career maturity and career decision status. The Career Development Quarterly, 49, 336-351.

Patton, W., Watson, M., \& Creed, P. A. (2004). Career maturity of Australian and South African high school students: Developmental and contextual explanations. Australian Journal of Career Development, 13, 33-41.

Perron, J., Vondaracek, F. W., \& Skorikov, V. B. (1998). A longitudinal study of vocational maturity ethnic identity development. Journal of Vocational Behavior, 59, 409-424.

Raskin, P. (1998). Career maturity: The construct's validity, vitality, and viability. The Career Development Quarterly, 47, 32-35.

Savickas, M. L. (1984). Career maturity: The construct and its appraisal. Vocational Guidance Quarterly, $32,222-231$.

Savickas, M. L., \& Hartung, P. J. (1996). The Career Development Inventory in review: Psychometric and research findings. Journal of Career Assessment, 4, 171-188.

Super, D. E. (1957). The psychology of careers. New York, NY: Harper \& Row.

Super, D. E. (1990). A life-span life-space approach to career development. In D. Brown \& L. Brooks (Eds.), Career choice and development (2nd ed., pp. 197-261). San Francisco, CA: Jossey Bass.

Super, D. E., Osborne, W. L., Walsh, D. J., Brown, S. D., \& Niles, S. G. (1992). Developmental career assessment and counseling: The C-DAC model. Journal of Counseling and Development, 71, 74-80.

Super, D. E., Thompson, A. S., Jordaan, J. P., Lindeman, R. H., \& Myers, R. A. (1988). Manual for Adult Career Concerns Inventory and the Career Development Inventory. Palo Alto, CA: Consulting Psychologists Press. 